\title{
Cultural and Economic Strategies of Modern China: In Search of the Cooperation Models across the Global World
}

\author{
Denys Svyrydenko \\ Doctor of Philosophical Sciences, Associate Professor, \\ Guangdong University of Petrochemical Technology \\ (Maoming, China) \\ E-mail: denis_sviridenko@ukr.net \\ https://orcid.org/0000-0001-6126-1747
}

\section{Oleksandr Stovpets}

\author{
Doctor of Philosophical Sciences (Dr. Hab. in Philosophy), Odesa National Maritime \\ University (Odesa, Ukraine) \\ E-mail: a.stovpets@gmail.com \\ https://orcid.org/0000-0001-8001-4223
}

Svyrydenko, Denys, and Oleksandr Stovpets (2020) Cultural and Economic Strategies of Modern China: In Search of the Cooperation Models across the Global World. Future Human Image, Volume 13, 102-112. https://doi.org/10.29202/fhi/13/11

The purpose of the article is a philosophical and anthropological study of the strategic models used by modern China in the cultural and economic fields. This study is based on the explication of the essential aspects of the so-called "Chinese dream". The key areas of cultural and economic activity of modern China are analyzed from the philosophical and anthropological positions, which are of strategic importance on the way to changing the current world geopolitical paradigm. Understanding the conceptual foundations of the evolution of Sinic civilization (headed by China) would make international relations more predictable and promising. The individual works of sinologists, cultural historians, and representatives of philosophical thought were useful for this study, in methodological terms. The scientific novelty of the study is expressed in the proposal to look at the whole array of diverse cultural, economic, geopolitical strategies used by China from the perspective of a holistic approach. Since economics and culture are closely related (and both of these areas focus on the modern man and the man of the future, finally), their symbiosis leads to emergence qualities that are constituted in a hybrid concept called the "Chinese dream". It forms the basis of the modern anthropological project of Chinese society. The analysis allows the authors to state that China is concentrating relevant cultural and political efforts on events that seek to increase the level of positive perception in the world of Chinese values and deepen the

(C) Svyrydenko, Denys, 2020

(C) Stovpets, Oleksandr, 2020 
dialogue of cultures in the global world. At the same time, large-scale economic interactions are being carried out as a part of the Belt and Road Initiative (BRI) strategic program, meaningfully transforming the global economic "agenda". The internal plan of the Chinese socio-economic strategy is associated with the creation and expansion of the so-called "middle-income society" as the main driving force on the path of the great revival of the Chinese nation. This movement is conceptualized in a multifaceted strategy with the symbolic name "Chinese dream", which differs significantly from its Western counterparts. As Chinese society moves from the modern era to the post-modern one, and the post-modern era itself in the socio-cultural landscape of China will initiate the need to find a conceptually updated anthropological project.

Keywords: China, a dialogue of cultures, cooperation in the era of globalization, an anthropological project of the future, middle-income society, Belt and Road Initiative (BRI), Chinese dream.

Received: January 15, 2020; accepted: March 11, 2020.

\section{Introduction}

The dynamics of the development of the modern Chinese society, the socio-cultural evolution of China, which occurs in parallel with the economic and technological growth, is associated with the transformation of ideas, values, ideas, and behaviors in all forms of its manifestation at the current historical stage. The indicated changes provide substantial food for thought that unfolds in the space of cultural anthropology, social philosophy, social anthropology, and other branches of socio-humanitarian knowledge.

Given that the latter focuses on the study of the mechanisms of human behavior within social groups, taking into account the structure of human social ties (traditions of socioeconomic and socio-political activity, the characteristics of national legislation and customary law, local religious and moral standards, established patterns of consumption and exchange, family relationships) — the entire array of these aspects of being can characterize more or less objectively the socio-cultural structure of a particular nation and say a lot about its mentality and value hierarchy. This stet of art, in its turn, contributes to a better understanding of the foreign and domestic policy of the state, which represents the corresponding ethnonational and socio-political community, with its specific culture. The era of globalization with an increase in the level of mobility of individuals and social structures in the process of their deployment rightly emphasizes the need to search for productive models of inter-cultural and, in general, intercultural communication (Savenkova \& Svyrydenko, 2018).

The proper understanding of the mental, ideological, socio-economic, spiritual patterns of other cultures is becoming increasingly significant as our world becomes more and more interdependent and genuinely global. Among this kaleidoscope of cultures, that substantively fill our modern world, the several ones stand out clearly from the background of many others, and almost always throughout the history of the world, either as a key or claiming to restore their lead in the development of human civilization.

China is one of those civilizations that, in the foreseeable future, will determine the fate of humanity along with other centers of power in the current multi-polar, multicultural world. What strategies does China choose for the successful implementation of the global globalization project? What socio-economic dominants does Chinese society determine for itself, and what kind of socio-cultural mission does modern China sees as its bearer? Let's consider some 
of the possible options, taking into account the Chinese cultural and philosophical tradition and the economic realities of our time. Without denying the importance of all the aspects mentioned above of the development and functioning of Chinese society, we focus primarily on the philosophical and anthropological content of modern models of cultural and economic strategies, which together determine the nature of Chinese geopolitics. This article is an attempt to philosophically interpret the results of studies that have been gained not only in the works of the famous philosophers, religion researchers but also in the modern sources in the field of global politics and international relations, economics, and the like. The key provisions of this article are the personal author's study, including the image of the man of future (future human image), which is the subject of broad academic discussion in the context of civilizational development, the contradictions of the interaction of different cultures, and the like.

We consider the individual studies to be methodologically essential to clarify the cultural and economic aspects of the modern Chinese strategy of being and development, in which such issues appear as following: the influence of spiritual and ideological factors on the public moral and legal system of China (Hang, 2011; Stovpets, 2019a; Stovpets, 2019b; Yao, 2001; Xing, 2013); the dialectic of democracy in the global world (Chan, 2007; Ding, 2008; Iskhakova, 2018; Yakushik, 2018); counter-consumerism (Gunderson, 2016); problems of technology and research in the global world (Bloom et al., 2019; Yeshchuk \& Vasina, 2019); features of China's international politics on a global day (Kyianytsia, 2019; Zalesny \& Goncharov, 2019).

\section{Purpose of Research}

The purpose of the article is a philosophical study of the most common cultural and socioeconomic models of a long-term, strategic nature that modern China practices both in foreign policy and domestically. Achievement of the stated goal is associated with the explication of how the Chinese state relies on human potential, combining the principles of utilitarianism (as the basis of economic growth and improving the quality of life); collectivism; socialism with Chinese characteristics, which is the essence of the Chinese vision of social justice; anthropocentrism; etc. At the same time, the strategy demonstrates the solidarity among the carriers of Sinic cultural codes.

\section{Statement of the basic materials}

China can rightfully be reckoned with the core of civil society, which has been considered for thousands of years as an attractor for the most diverse ethnic groups, gaining them up to its own cultural and economic expanse, absorbing and assimilating them. History shows many examples when carriers of other cultures (Xiongnu, Miao, Uyghurs, Mongols, Manchu, and others, once self-sufficient peoples) fall into the "Chinese melting pot". The ethnic groups mentioned above can retain their dialects, individual traditions, and even religious characteristics. Still, mentally they become part of the Sinic culture and, no less critical, successfully integrate into the Chinese socio-economic system. These processes can go on for centuries.

The development of human potential in China has always been associated with an imperial power whose modus vivendi has become an economic and cultural expansion. This vector was somewhat disrupted in the 19th century (The Opium Wars in Chinese historiography). However, taking into account the long and rich history in the field of conceptualizing power and the Confucian heritage, the revival in China of strategies and tactics of cultural and other 
types of influence, which are collectively referred to as the term "soft power", was only a matter of time. However, the content of these models, historically rooted in the imperial past, requires rethinking, adjusted for modern technological, geopolitical, socio-economic realities that prevail in the world now.

It is worth considering that the traditional culture of China has a particular specificity, and is often seen as too conservative. At the same time, in recent years, Chinese culture has found successful translation mechanisms beyond the traditional space of the Sinic civilization, actively involving the non-governmental sector to implement the ideas of cultural diplomacy in the global space. The soft power of the Chinese cultural policy becomes possible, first of all, thanks to its active cultural presence in various countries through the developed networks of intercultural cooperation.

For this purpose, Confucius Institutes and "classes" are being established in different parts of the world - an international network of cultural and educational centers created with the participation of the Office of Chinese Language Council International, in the daily discourse known as Hanban. This organization was founded in 1987, and the most prominent among its functions is the creation and expansion of the Confucius Institutes network. The announcement of the creation of the first Confucius Institute in Seoul in 2004 marked a new phase of cultural and political activity in China when objective resource and program prerequisites were created to deepen intercultural dialogue and popularize Chinese culture in the global world (Starr, 2009: 65).

To demonstrate the dynamics of the international cultural activity of the PRC, we present some statistics. Therefore, as of the end of 2010 , there were already 322 Confucius Institutes and 369 Confucius Classes in 96 countries worldwide. As of 2018, China ensured its permanent cultural presence in 142 countries and regions of the world, in which 516 Confucius Institutes and 1076 Confucius Classes functioned together. In China itself, there are about 1800 Confucius schools (Zin, 2018). In 2019, 548 Confucius Institutes and 1,193 Confucius schools and classes worked in 162 countries and regions of the world. Due to substantial government funding, China plans to have 1,000 such institutions abroad collectively by the end of 2020, marking such dynamics by the "Confucius Revolution", and aiming to meet the growing world demand for learning the Chinese language (Jakhar, 2019). According to official Hanban data, 187 institutions are currently functioning in Europe (in particular, six Institutes and two Confucius classes in Ukraine), 138 institutions in North and South America (in particular, 81 institutes and 13 Confucius classes in the USA), 135 institutions in Asia (Confucius Institute, 2020).

Confucius Institutes, open to the broad groups of participants, popularize the Chinese language as well as Chinese culture, from calligraphy and cooking to tai chi and Chinese classical philosophy. These structures implement educational exchange programs, conduct public events, and lectures. Confucius institutes are directly responsible both for the spread of the Chinese language in various countries of the world and for the familiarization of their population (intellectuals and the general public) with the history of China. Another essential task identified by Hanban is to preserve the language in the circles of the Chinese diaspora. The fact is that many young ethnic Chinese belonging to the second and third generations of emigrants, for the most part, know only the spoken language (and, often, this is a particular dialect of Chinese and not the classical version). At the same time, they may not have Chinese writing at all.

In general, it can be noted that the mentioned cultural and educational structure fulfills its 
mission - to contribute to the global, soft and dialogic popularization of Chinese spiritual values, to make China more understandable to the rest of the world, to achieve moral leadership, successfully applying cultural diplomacy approaches. Within Confucian thinking, moral leadership is also part of "soft power". This vision resonates with the Chinese cultural and intellectual traditions, echoing with a traditional anthropological project.

As it is known, the basis of the original paradigm of the Chinese system of government is Confucianism. Despite its hierarchy, the Confucian paradigm is built on the principles of ethics. They expect moral superiority from the ruler, which (among other personal qualities) facilitates the adoption of wise decisions to support the security and prosperity of the state. As long as the ruler and his actions meet the criteria of Confucian morality, one is considered worthy of the "mandate of Heaven" and the comprehensive support of one's citizens. If one deviates from moral standards, then it is considered that he is no longer worthy of heavenly intercession and loses the right to own a "mandate" (Chan, 2007: 179).

China's successful cultural expansion, demonstrating the ideals of a new Confucianism, is only one side of modern Chinese strategy. If we look at the economic policy of the PRC of recent decades, in particular, foreign economic (Arroyo, 2008), it can be assumed that the Chinese "economic strategies" are also designed for the long term and aimed at cooperation with representatives of other civilizational and cultural spaces. A striking example is the Belt and Road Initiative (BRI) strategic program, which China has been successfully implementing in recent years.

Taken into account the current trends in the development of the international relations with the participation of China, as well as the turning political events of recent years in China itself, we can assume that this country is reviving its significant civilizational status successfully now. The fact is that China has almost always been a super-state and surpassed other civilizations of the world (including European one) in many development indicators: in terms of population and population growth rate, literacy rate, gross domestic product, and the like. Not to mention the national cultural identity that prevailed in Imperial China much earlier than in the West.

However, China, when it was an empire under the rule of great ancient dynasties — The Qin dynasty, The Han dynasty, The Tang dynasty, The Song dynasty, The Yuan dynasty, The Ming dynasty, The Great Qing dynasty, was still a regional superpower. Despite its economic, scientific, educational, military-political, and cultural leadership status in East Asia at that period, China dissociated itself from non-Chinese civilizations. China limited its interaction with them to trade and the minimum necessary diplomatic relations.

The situation described above ended in the 19th century. This great empire has already become accustomed to leadership, to its status of "Celestial Empire", has found itself in a situation of the need to take into account the technological capabilities, socio-cultural achievements, and geopolitical ambitions of Europe. For some time, China was dependent on Britain and other Western states, then on Japan, until the end of World War II. Only from the middle of the 20th century, China once again embarked on the path of a revival of one's true great civilizational status. We, like many other researchers, tend to think that the Chinese success strategy is becoming global because China is not just soon, but today it is demonstrating the economic leadership in the world in many ways. This state of things allows us to designate the geopolitics of China as "a return to mega-empire".

Mega-empire is an empire that exists not only in the space of its territory, and not only within the framework of a single monolithic nation. It goes far beyond its borders, offering models of cooperation and development in many other countries, even if they have entirely 
different political and socio-economic systems and cultural codes. Once such mega-empires were the empire of Alexander the Great and the Roman Empire. They spread their effective examples of the political and socio-economic structure, technologies, and other attributes of material and spiritual culture.

It makes sense to analyze the cultural influence of China in the modern world in the context of the so-called "information power", which is functionally connected with educational and cultural institutions, the media, and intellectual property institutions (Stovpets, 2017: 54). Today, China is confidently growing its world status in the field of intellectual activity, actively realizing its potential as a country-innovator. From year to year, the number of Chinese developments, brands, patents, scientific discoveries, technological advances are growing. It indicates the turn of the Chinese economy towards innovation, which gives reason to expect the emergence of new anthropological challenges that naturally arise in societies as a result of the transition to a post-industrial matrix (in the economy) and a post-modern paradigm (in the general cultural space).

These transformations of material and spiritual content have a direct impact on the anthropological project, which underlies this or that society. After all, innovations represent a complex socio-cultural phenomenon, the determinants of which are specific features of the social environment, and the current anthropological project. Therefore, it is logical that the vector of social transformations related to information and communication and other determining innovations, from the technical, economic and legal spheres, is moving now into the socio-cultural plane (Stovpets, 2016a: 11). And this is especially noticeable in China, which, for example, created and made universal (in its social space) Chinese national communication technologies (search engines, instant messengers, social networks, online trading platforms, etc.). They are not inferior to Western counterparts in popularity in China itself, and in some aspects (in particular, in terms of the level of tool functionality integration, by the criteria of efficiency and ease of use) they are even ahead of similar technological tools used in Europe and the USA. All of this significantly affects people's lifestyles. The information society in China is developing very dynamically, which leads to increased human potential and the gradual renewal of the "Chinese Anthropological Project".

Why is today's China an economic superpower? In our opinion, it is a consequence of the economic philosophy that country has been implementing since the late 1970s. However, not only that. "Mega-empire" is impossible without the active translation of its cultural tradition and value-meaning constructs. Therefore, not accidentally Xi Jinping declares publicly that China, through its development, makes a considerable contribution to the development of humankind. Also, it is announced that China forms around itself the community "Community of Shared Future for Mankind", also known as the "Community of Common Destiny". China productively combines cultural diplomacy approaches with economic cooperation with "Common Destiny countries" by investing in joint projects.

"Mega-Empire" as a specific social architecture at all times has always been based on two postulates: the army (the reports of Xi Jinping repeatedly fix the task of making the PRC army the most powerful army in the world by 2050) and the economy. Evidence of economic power is, in particular, the ability of China to support its partner countries continually by attracting investment in their economies. An example of such investments is financing the development of infrastructure - highways, warehouses, logistics complexes within the Belt and Road Initiative (BRI).

Next, we come to the question of the degree of China's integration into the so-called 
post-modern reality, demonstrating the successes of this state in implementing the national and international economic development strategies. However, we need to clarify something to understand the paradigm sequence "Premodernity - Modernity - Postmodernity", on the concept of which we also rely on our philosophical and anthropological searches. We agree with the thesis that the same chronological moment for representatives of different social groups and cultures produces some non-identical ways of coexistence. Namely, this phenomenon in socio-humanitarian discourse is framed conceptually by the concept of "social time" (Sorokin \& Merton, 2004: 113). At the same time, informatization, globalization, and other technological and anthropological factors make significant adjustments to the sociocultural dynamics of the historical process and the characteristics of social time.

Postmodernism is a possible future era. However, even for the avant-garde part of Western civilization, postmodernity has not come yet. We are witnesses of tectonic socio-cultural and anthropological transformations of the transit from modern to post-modern. Logically, the specifics of this transition for Western and Eastern civilizations should be studied with an understanding of the particulars of its current modern-day state, when postmodernity should be considered as a close or distant prospect of completing the transit mentioned above.

China, in previous times, in most cases, watched somewhat distantly the turbulent events in the West, limiting its communication with Western civilization with trade operations. For the Chinese value system, the worldviews of Europeans were quite alien (Svyrydenko \& Fatkhutdinov, 2019). Everything that happened in the history of European civilization for about 500 years (15-19 centuries), led to the fact that at the beginning of the twentieth century, the construction of the "modern project" in Europe was completed.

One can agree with the opinion that the spiritual foundations of the modernization of European culture are read in the philosophy of the Enlightenment, in particular, in the rationalization and dissemination of ideas of the political, economic and spiritual independence of the individual, the recognition of one's rights to one's initiative and sovereignty, one's identity as a public good.

In our previous studies of the features of transit to the post-modern state of development, we formulated the following thesis: "With the transition from "pre-modern" to modern, a person of the Western civilization receives a kind of a set of basic cultural codes that become decisive for his development. A person gets modern education, modern consciousness, modern language, modern technologies, social practices, and modern institutions" (Stovpets, 2016b: 117). The ideology of modernity makes special bets on the human potential of the individual, and, as a tool for revealing this potential, defines liberalism and individualism (contrasting them with statism and collectivism). And here we come to the problems of postmodernism in "Western" and "non-Western" societies.

If one talks about such signs of postmodernism as decentralization, de-ideologization, erosion of national-state sovereignty, excessive individualism. Today, we do not see sufficient reason to speak about postmodernity paradigm in China. However, we see that New Confucianism, socialism with Chinese characteristics, statism, political pragmatism, a nationstate are the minimal set of signs that determine the life of modern Chinese society, and all of these have modernity features indeed. It is also worth considering the features of the Chinese legal mentality, which can be summarized as "philosophical and legal syncretism" (Stovpets, 2019a: 59).

Indeed, in the economic sphere, China has leaped the post-industrial formation (bringing Chinese society closer to "postmodernity"). Under the leadership of Hu Jintao, in the first 
decade of this century, China continued to strengthen its status as an economic superpower. However, Hu Jintao's domestic policy had two main components: the continuation of economic reforms and the preservation of traditional public policy. The recipe, which was implemented in social practice in a productive form, was a combination of the approaches of economic liberalization with the policy of social control.

This course was continued with the advent of Xi Jinping in China in 2013. At the same time, this leader took into account the successful experience of his predecessors. If Hu Jintao, during his presidency in China, supplemented the ideology of a "socialist harmonious society" with the concept of scientific development (based on the achievements of Deng Xiaoping and Jiang Zemin), then Xi Jinping adopted the idea of "integrated state power". It provides for a solid foreign policy of the PRC, which claims to be the world conductor of free trade and economic globalization. The political creed of Xi Jinping is the Great Power Diplomacy with Chinese Characteristics. The concept mentioned above made a significant contribution to the development of the discourse of "soft power". It was born in the process of adapting the wellknown theory of Joseph Nye (Nye, 2004). Moreover, this complex power consists of "hard power", "soft power" and the coordinating power of the state, and it is the latter (through sociopolitical structures) that receives leverage for more practical use of "soft power" (Callahan \& Barabantseva, 2011: 231).

Why, in fact, do we have the reason to assert that the "modern" with clear evidence so far dominates the "post-modern" in the life of today's China? The fact is that China (along with other key countries in Asia) is experiencing an upsurge in the national identity. Civic (non-ethnic) nationalism quite confidently integrated into China's public policy. It is not by chance that Xi Jinping proclaimed "the great revitalization of the Chinese nation" as one of the main slogans of his reign. An appeal to the idea of a "great nation" is a characteristic sign of the worldview of the modern era, after which the conceptualization of the "national state" took place. As it's known, the peak of the construction of a system of sovereign nations was observed in pre-war Europe of the late 19 - early 20th centuries. According to some researchers, today, some Asian countries are most close to the so-called Westphalian type of state producing the corresponding meta-narratives (Alagappa, 2003: 87).

Desiring to reduce the potential impact of globalization on Chinese society, productively resolving the "local-global" contradictions, as well as fixing the tendency to "great revival", the project "The Chinese Dream" has recently been implemented in the social practice (Xi Jinping, 2013). This concept is multifaceted because it integrates both the modern socioeconomic interests of China and the cultural-historical, political-ideological sphere, and worldview issues. This concept should be the subject of further philosophical research.

\section{Discussion Statements}

The article proposes to consider an array of diverse cultural, economic, geopolitical stratagems used by China, from the perspective of a holistic approach. Since economics and culture are closely related (and both of these areas are finally closed to humans), their symbiosis leads to emergent qualities that are constituted in a social concept called "The Chinese Dream". Structural, functional, and system analysis suggests that the Chinese strategic model is essentially connected with the idea of continuous economic expansion towards obtaining world leader status, with the parallel global presence of Chinese culture through the creation of its cells in different countries. It can be concluded with a certain degree of conditionality that 
understanding the conceptual foundations of the evolution of the Sinite civilization (headed by China) will make international relations more predictable and promising, creating a space for productive cultural communication and cooperation.

\section{Conclusions}

Thinking about the current model of the representation of modern Chinese geopolitics in the cultural and economic plane, we can fix some observations. Firstly, it should be noted that since the introduction of the Opening Up and Reform Policy, the emphasis has been done on maximizing the development of human potential. This fact "opened" the broad opportunities for personal self-realization in private areas (primarily in the business environment), causing the significant liberalization of life.

The productive combination of the paternalism with competitive principles (in the domestic market), the growth of the Chinese middle class, the intensification of academic mobility, the increase in the level of innovativeness of the PRC economy, as well as the revival of Confucianism and other traditions in culture, - the whole this complex makes the Chinese anthropological project successful on a global scale today.

As for China's foreign cultural strategy, the main tool for its implementation is the intention to ensure its cultural presence in various countries of the world, implementing cultural diplomacy approaches in the global world. This task, in general, is accomplished by opening the Confucius Institutes and Confucius Classes, as has been mentioned above. China today practices some forms of popularizing its own culture, implementing many international cultural exchange programs (such as The Visiting Program for Young Sinologists, Chinese Bridge, and others, coordinated by the Ministry of Culture and Tourism of the PRC, the Ministry of Education of the PRC, and the Chinese Academy of Social Sciences (CASS), etc.). In its entirety, all these institutions make China by their activities, closer and more understandable to other cultures. In the end, they add their contribution to the positive perception of the entire Sinic civilization, the core of which is China.

The economic strategy of China contains two interrelated components. The international financial part of modern Chinese strategy correlates with the well-known trade and infrastructure project named "Belt and Road Initiative" (BRI), with well-developed investment practices, cross-border infrastructure development, and the like. However, the internal economic component is no less important here, the state of realization of which affects the rest of the modern globalized world. We are talking about the active development of the Chinese middle class, the so-called "Moderately prosperous society" (Xiaokang), which forms the material basis of the concept of "The Chinese Dream". The spiritual basis of economic transformations is the Sinite cultural tradition, in particular, New Confucianism, the revival of Chinese philosophy, and the spread of the Chinese language.

The concept of the "Chinese dream" is a socio-cultural, political-ideological, and socioeconomic idea of a hybrid (in a positive sense) nature. It absorbed both the features of individualism (to encourage individual private entrepreneurship, moderate consumerism, competition). It proclaimed the collective ideals of the "great rebirth" of the Chinese nation to achieve great common goals. The "Chinese dream" is successfully realizing itself as an instrument of ethical justification for China's further economic growth.

We were able to demonstrate that modern Chinese society is developing mainly on the ideals of modernity when the nation-state was considered the highest public domain. The post- 
modern era, which is likely to begin for China in the foreseeable future, will offer a unique post-modern project with Chinese characteristics, in the center of which there will be a specific anthropological project. We do not exclude that the latter will differ significantly from its western models, and it will become a source of anthropological challenges on a global scale.

\section{References}

Alagappa, M. (2003) Asian Security Order: Instrumental and Normative Features Stanford: Stanford University Press.

Arroyo, Dennis (2008) The Political Economy of Successful Reform: Asian Stratagems. https://kingcenter.stanford.edu/publications/political-economy-successful-reformasian-stratagems

Bloom, Nicholas, Van Reenen, John, and Heidi Williams (2019) A Toolkit of Policies to Promote Innovation. Journal of Economic Perspectives, 33 (3), 163-184. https://doi. org/10.1257/jep.33.3.163

Callahan, William, and Elena Barabantseva (2011) China Orders the World: Normative Soft Power and Foreign Policy. Washington: Woodrow Wilson Center Press.

Chan, Joseph (2007) Democracy and Meritocracy: Toward a Confucian Perspective. Journal of Chinese Philosophy, 34(2), 179-193. https://doi.org/10.1111/j.1540-6253.2007.00408.x

Confucius Institute / Classroom. http://english.hanban.org/node_10971.htm

Gunderson, Ryan (2016) The Will to Consume: Schopenhauer and Consumer Society. Critical Horizons, 17 (3-4), 376-389. https://doi.org/10.1080/14409917.2016.1190181

Ding, Liqun (2008) The basic nature of cultural philosophy. Social Sciences in China, 29 (4), 143-152. https://doi.org/10.1080/02529200802500466

Jakhar, Pratik (2019) Confucius Institutes: The growth of China's controversial cultural branch. BBC Monitoring, September 7, 2019. https://www.bbc.com/news/world-asiachina-49511231

Hang, Lin (2011) Traditional Confucianism and its Contemporary Relevance. Asian Philosophy, 21 (4), 437-445. https://doi.org/10.1080/09552367.2011.635896

Iskhakova, Natalia (2018) Trust as a Factor of Political Mobilization of Society in the Conditions of Establishment of Democracy. Ukrainian Policymaker, 3, 11-16. https:// doi.org/10.29202/up/3/2

Kyianytsia, Leonid (2019) A 'Triangular' Relationship with the Great Powers: The Case of the post-Cold War Vietnam Balancing versus China and the USA. Ukrainian Policymaker, 5, 44-52. https://doi.org/10.29202/up/5/5

Nye, Joseph (2004) Soft Power: The Means to Success in World Politics. New York: Public Affairs Group.

Savenkova, Lyudmila, and Denys Svyrydenko (2018) Academic Mobility and Academic Migration Issues: the Case of Ukrainian Higher Education. Interdisciplinary Studies of Complex Systems, 13, 57-65. https://doi.org/10.31392/iscs.2018.13.057

Sorokin, Pitirim, and Robert Merton (2004) Social Time: the experience of methodological and functional analysis (translated by N. Romanovskiy). Sociological Studies, 6, 112 119

Starr, Don (2009) Chinese Language Education in Europe: the Confucius Institutes. European Journal of Education, 44 (1), 65-82. https://doi.org/10.1111/j.1465-3435.2008.01371.x

Stovpets, Oleksandr (2016a) The problem of innovation in the context of intellectual property 
research: from the economic-juridical into the socio-cultural paradigm. Grani, 19 (7), 6-12. https://doi.org/10.15421/171625

Stovpets, Oleksandr (2016b) Premodernity and Modernity: prolegomenon to the designation of postmodernity in the context of research for Intellectual Property institution. ISJ Theoretical \& Applied Science, 12 (44), 115-123. http://doi.org/10.15863/ TAS.2016.12.44.22

Stovpets, Oleksandr (2017) Social-philosophic view of the Intellectual Property institution: contemporary features, main problems \& development prospects. Cogito: Multidisciplinary Research Journal (REVISTĂ DE CERCETARE ŞTIINŢIFICĂ PLURIDISCIPLINARĂ), IX (1), 49-64. http://cogito.ucdc.ro/cogito-march2017.pdf

Stovpets, Oleksandr (2019a) Chinese legal-philosophic syncretism, and its influence to value orientations of Chinese society. Skhid, 1 (159), 55-60. https://doi.org/10.21847/17289343.2019.1(159)

Stovpets, Oleksandr (2019b) Intellectual Property Transformation in China under the Influence of Confucian Philosophy and Socialism with Chinese Characteristics. Confucian Academy. Chinese Thought and Culture Review, 6 (3), 68-99. http://big5. oversea.cnki.net $/ \mathrm{kcms} /$ detail/detail.aspx?filename=KXTK201903009\&DBName= cjfdtotal\&dbcode $=$ cjfd

Svyrydenko, Denys, and Vasyl Fatkhutdinov (2019) The Identity Issues at the Perspectives of Chinese Geopolitical Strategies. Studia Warmińskie, 56, 81-94. https://doi. org/10.31648/sw.4599

Xi Jinping and the Chinese dream (2013) The Economist, May 4, 2013. http://www.economist. $\mathrm{com} /$ news/leaders/21577070-vision-chinas-new-president-should-serve-his-peoplenot-nationalist-state-xi-jinping

Xing, Guang (2013) Buddhist Impact on Chinese Culture. Asian Philosophy, 23 (4), 305-322. https://doi.org/10.1080/09552367.2013.831606

Yakushik, Valentyn (2018) The Timeless Value of a Pluralistic World. Future Human Image, 10, 123-135. https://doi.org/10.29202/fhi/10/13

Yao, Xinzhong (2001) Who is a Confucian Today? A Critical Reflection on the Issues Concerning Confucian Identity in Modern Times. Journal of Contemporary Religion, 16 (3), 313-328. https://doi.org/10.1080/13537900120077140

Yeshchuk, Olga, and Anna Vasina (2019) Chinese Space Law: Problems and Areas of Reforming. Advanced Space Law, 3, 140-150. https://doi.org/10.29202/asl/2019/3/12

Zalesny, Jacek, and Vitaly Goncharov (2019) Ontological Core of the Social Concept of Global Constitutionalism: a Socio-Philosophical Analysis of Content and Evolution.

Future Human Image, 12, 129-142. https://doi.org/10.29202/fhi/12/12

Xin, Zhou (2018) China has 1,800 Confucius schools: foundation. http://www.xinhuanet.com/ english/2018-03/15/c_137041573.htm 